\title{
PENGALAMAN PASIEN GAGAL GINJAL KRONIK DALAM MENJALANI HEMODIALISIS DI RUMAH SAKIT ADVENT BANDUNG
}

\author{
EXPERIENCE OF PATIENTS WITH CHRONIC KIDNEY DESEASE IN \\ HEMODIALYSIS AT BANDUNG ADVENTIST HOSPITAL
}

\author{
Yunus Elon ${ }^{1}$, Gatot Dahono Dewadi ${ }^{2}$ \\ Fakultas IImu Keperawatan, Universitas Advent Indonesia \\ E-mail: yunus.elon@unai.edu
}

\begin{abstract}
ABSTRAK
Pendahuluan: Hemodialisis merupakan suatu upaya terapi pengganti ginjal yang sudah tidak bisa melakukan fungsi atau tugasnya. Tujuan: Penelitian ini bertujuan untuk mengetahui gambaran pengalaman pasien dalam menjalani hemodialisis. Metode: Jenis penelitian ini adalah kualitatif dengan metode fenomenalogi. Penelitian ini melibatkan 7 orang Key Informant dengan teknik purposive sampling, yang memenuhi kriteria dan merupakan pasien hemodialisis. Pengumpulan data dilakukan dengan cara wawancara yang dilengkapi dengan pedoman wawancara. Wawancara direkam kemudian di buat transkrip verbatim dan dianalisis dengan metode Colaizzi. Hasil: Hasil penelitian ini didapati gambaran pengalaman pasien saat pertama kali melakukan hemodialisis adalah cemas, kaget, syok, ketakutan, tidak menerima, gelisah, kuatir, tidak percaya, stres, pasrah dan berdoa. Setelah 5 tahun menjalani hemodialisis biasa-biasa saja, tidak terlalu cemas, pasrah kepada Tuhan, mengalami perubahan, kondisi kesehatan lebih baik, menerima, gembira, senang, lebih fit, berhati-hati dalam makan dan minum. Faktor yang paling berpengaruh terhadap kualitas hidup pasien adalah faktor fisik. Koping pasien dalam menjalani hemodialisis di Rumah Sakit Advent Bandung adalah informan berusaha untuk menangani tantangan yang dihadapi selama menjalani hemodialisis yaitu: menemukan solusi lain, mengikuti anjuran dokter dan perawat, mendekatkan diri pada Tuhan, makan dan minum teratur, membatasi minum, berdoa dan bersyukur kepada Tuhan. Diskusi: Manfaat penelitian ini bagi pasien hemodialisis adalah sebagai motivasi bagi pasien untuk dapat memanfaatkan terapi hemodialisis sebaik mungkin dalam membantu pasien bertahan hidup dan mengontrol perilaku ketaatan pasien dalam menjalani terapi.
\end{abstract}

Kata kunci: Pengalaman, Hemodialisis

\begin{abstract}
Introduction: Hemodialysis is an attempt of renal replacement therapy that cannot perform its functions or tasks. Purpose: This study aims to describe the experience of patients in hemodialysis. Method: Type of this research is qualitative with phenomenology method. This research involves 7 Key Informant people with purposive sampling technique, which meets the criteria and is a patient of hemodialysis. Data collection was done by interviewing equipped with a guidance interview. Interviews were recorded and then made verbatim transcripts and analyzed by Colaizzi. Results: The results of this study found a picture of patients experience the first time patient perform hemodialysis is anxious, shocked, shock, fear, do not accept, anxiety, worry, do not believe, stress, let go and pray. After 5 years of hemodialysis mediocre, not too worried, surrender to God, unchanged, better health conditions, receive, excited, happy, more fit, to be careful in eating and drinking. The factors that most affect the quality of life of patients is physical. Hemodialysis patients
\end{abstract}

JURNAL

SKOLASTIK

KEPERAWATAN

Vol, 4, No. 2

Juli - Desember 2018

ISSN: $2443-0935$

E-ISSN 2443 - 16990 
coping in Bandung Adventist Hospital is an informant trying to deal with the challenges faced during hemodialysis are: find other solutions, follow the advice of doctors and nurses, get closer to God, eat and drink regularly, limit drinking, praying and thanking God. Discussion: The benefit of this study for hemodialysis patients is as a motivation for patients to be able to utilize hemodialysis therapy as well as possible in helping patients survive and control the behavior of patient compliance in therapy.

Keywords: Experience, Hemodialysis.

\section{PENDAHULUAN}

Gagal ginjal Kronik (GGK) merupakan gangguan pada fungsi ginjal yang sifatnya progresif atau tidak dapat pulih kembali, kondisi ini mengakibatkan kegagalan ginjal dalam melakukan proses metabolisme atau pembuangan zat-zat sisa dalam tubuh sehingga mengakibatkan peningkatan kadar ureum dalam darah. Tindakan yang dapat dilakukan untuk mempertahankan kelangsungan hidup pasien dengan GGK yaitu; transplantasi ginjal, dialisis peritoneal, hemodialisis dan rawat jalan dalam jangka waktu yang lama (Desfrimadona, 2016).

Gagal ginjal merupakan masalah kesehatan dunia dilihat dari terjadinya peningkatan insidensi, prevalensi, dan tingkat morbiditasnya. Berdasarkan data di

United States Renal Data System, penyakit gagal ginjal kronik meningkat sebesar 20-25\% setiap tahunnya. Indonesia termasuk negara dengan tingkat penderita gagal ginjal yang cukup tinggi. Hasil survei yang dilakukan oleh Perhimpunan Nefrologi Indonesia (Pernefri) diperkirakan ada sekitar 12,5 persen dari populasi atau sebesar 25 juta penduduk mengalami penurunan fungsi ginjal. Ekantari, Suswardani, \& Kusumawati (2012, hal.
4) mengemukakan angka kejadian gagal ginjal di dunia secara global lebih dari 500 juta orang dan yang harus menjalani hidup dengan bergantung pada cuci darah (hemodialisis) 1,5 juta orang.

Di Indonesia pada tahun 2015 terdapat 21.050 pasien baru yang menjalani hemodialisis dan pasien yang aktif sebanyak 30.554. Terjadi peningkatan pasien yang menjalani hemodialisis dibandingkan dengan tahun 2014 terdapat pasien baru berjumlah 17.193 dan pasien aktif sebanyak 11.689 (Indonesian Renal Registry (IRR), 2015). Hemodialisis di Indonesia sudah dimulai sejak tahun 1970 dan sampai sekarang telah dapat dilaksanakan di rumah sakit rujukan (Sunarni, 2009) dalam (Dani, Utami, \& Bayhakki, 2015, hal. 1362).

Doengoes (2010) dalam (Alfiannur, Nauli, \& Dewi, 2015, hal. 1107) mengemukakan bahwa masing-masing pasien yang menjalani hemodialisis biasanya memiliki respon yang berbeda terhadap hemodialisis yang sedang dijalaninya, contohnya pasien merasa cemas yang disebabkan oleh krisis situasional, ancaman kematian, dan tidak mengetahui hasil akhir dari terapi yang dilakukan tersebut. Pasien dihadapkan pada ketidakpastian berapa 
lama hemodialisis diperlukan sepanjang hidupnya serta memerlukan biaya yang besar.

Hasil penelitian yang dilakukan oleh Hagita, Bayhakki, dan Woferst (2015) tentang studi fenomenologi kualitas hidup pasien gagal ginjal kronik yang menjalani hemodialisis di Rumah Sakit Umum Daerah (RSUD) Arifin Achmad Pekan Baru didapati ada 8 masalah atau tema yang dialami oleh pasien hemodialisi yaitu: 1). Penurunan pemenuhan kebutuhan fisiologis (fisik lemah, gangguan tidur, gangguan bernapas, gangguan makan, gangguan pada kulit, gangguan eliminasi, dan gangguan sirkulasi 2). Respon psikologis (timbul perasaan negatif meliputi: takut, stress, syok, depresi, sedih, menangis dan kesal). 3). Respon spiritual meningkat (meningkatkan ibadah dan pasrah dengan keadaanya), 4). Perubahan interaksi sosial (penurunan frekuensi bersosialisasi dan sosialisasi berkurang yang diakibatkan oleh fisik yang lemah), 5). Dukungan yang dibutuhkan (diperhatikan, dukungan keluarga dan dukungan lingkungan kerja atau teman), 6). Perubahan status ekonomi (kebutuhan keuangan bertambah dan pendapatan keuangan berkurang), 7). Penurunan kualitas hidup fisik dan psikologis, 8). Adaptasi (membatasi aktifitas dan dari menerima keadaan).

Data yang didapat dari Rumah Sakit Advent (RSA) Bandung setiap tahun terdapat penambahan jumlah pasien hemodialisis. Pada tahun 2012 ada 95 orang yang menjalani terapi hemodialisis tahun 2013 sebanyak 98 orang, tahun 2014 mengalami penurunan menjadi 82 orang namun tahun 2015 meningkat menjadi 118 orang, tahun 2016 ada 121 orang dan semakin bertambah lagi di tahun 2017 yaitu 133 orang yang menjalani terapi hemodialisis.

Menurut pengamatan peneliti selama bekerja 9 tahun di ruang hemodialisa RSA Bandung setiap tahunnya pasien hemodialisis selalu mengalami peningkatan baik perempuan maupun laki-laki dari usia remaja sampai orang tua. Pasien yang pertama kali melakukan hemodialisis terlihat sangat cemas, takut dan khawatir sehingga selalu bertanya tentang keadaannya tidak hanya pasien yang baru pertama kali menjalani hemodialisis namun hal ini juga dialami pasien yang sudah melakukan hemodialisis selama bertahun-tahun. Perasan cemas takut dan khawatir akan keadaan kesehatan, perkembangan, dan selama proses hemodialisis sehingga menyebabkan pasien gelisah berlebihan. Selama proses hemodialisis berlangsung peneliti mengamati bahwa banyak pasien terlihat murung, kurang semangat, takut gelisah, dan kurang percaya diri.

\section{METODE}

Teknik pengumpulan data dilakukan secara trianggulasi (gabungan), analisa data bersifat induktif, dan hasil penelitian kualitatif lebih menekankan makna dari pada generalisasi.

Populasi yang diikutsertakan dalam penelitian ini adalah pasien hemodialisis di Rumah Sakit Advent Bandung. Sampel atau contoh adalah submit populasi survei atau populasi survei itu sendiri, yang oleh peneliti 
dipandang mewakili populasi target. ). Sampel dalam penelitian ini ada 7 pasien yang menjalani hemodialisis \pm 5 tahun dengan frekuensi 3 kali seminggu.

\section{HASIL DAN PEMBAHASAN}

\section{Data Informan Peneliti}

Peneliti melakukan wawancara mendalam dengan menggunakan panduan wawancara. Wawancara ini membutuhkan 30 menit dalam setiap kali dilakukan wawancara. Peneliti melakukan wawancara minimal 2 kali (1 kali wawancara dan 1 kali konfirmasi) dalam melakukan wawancara bila ada informasi yang kurang. Ada 7 informan dari pasien hemodialisis di Rumah Sakit Advent Bandung yang bersedia dan memenuhi syarat untuk melakukan wawancara bersama peneliti.

Berikut adalah deskripsi informan dalam tabel 1 di bawah ini:

Tabel 1 Deskripsi Data Informan

\begin{tabular}{|l|l|l|l|l|}
\hline No & Inisial & Umur & $\begin{array}{l}\text { Jenis } \\
\text { Kelamin }\end{array}$ & $\begin{array}{l}\text { Lama } \\
\text { menjalani } \\
\text { Hemodialisa }\end{array}$ \\
\hline 1. & $\begin{array}{l}\text { Tn. } \\
\text { JOG }\end{array}$ & $\begin{array}{l}60 \\
\text { tahun }\end{array}$ & Laki-laki & 7 tahun \\
\hline 2. & Ny. Ln & $\begin{array}{l}56 \\
\text { tahun }\end{array}$ & Perempuan & 12 tahun \\
\hline 3. & Tn. D & $\begin{array}{l}38 \\
\text { tahun }\end{array}$ & Laki-laki & 6 tahun \\
\hline 4. & Ny. A & $\begin{array}{l}47 \\
\text { tahun }\end{array}$ & Perempuan & 6 tahun \\
\hline
\end{tabular}

\begin{tabular}{|l|l|l|l|l|}
\hline 5. & Ny. DA & $\begin{array}{l}54 \\
\text { tahun }\end{array}$ & Perempuan & 7 tahun \\
\hline 6. & Tn. BK & $\begin{array}{l}71 \\
\text { tahun }\end{array}$ & Laki-laki & 7 tahun \\
\hline 7. & $\begin{array}{l}\text { Tn. } \\
\text { MS }\end{array}$ & $\begin{array}{l}69 \\
\text { tahun }\end{array}$ & Laki-laki & 6 tahun \\
\hline
\end{tabular}

2. Gambaran pengalaman pasien dalam menjalani hemodialisis di Rumah Sakit Advent Bandung

Berdasarkan hasil wawancara yang diperoleh dari 7 pasien hemodialisis yang bersedia untuk diwawancarai secara mendalam didapati bahwa semua informan mempunyai pengalaman dalam menjalani hemodialisis terbagi menjadi dua bagian:

1) Pertama kali menjalani hemodialisis: dari ketujuh informan didapati bahwa merasa cemas 5 orang; kaget, tidak menerima keadaan, merasa gelisah, merasa kuatir 2 orang; syok, tidak percaya, stres, pasrah, berdoa 1 orang; merasa ketakutan 6 orang.

Informan memberi penjelasan terhadap pengalaman pertama kali menjalani hemodialis yang mereka alami. Menurut Trianto (2008, hlm. 12) pengalaman adalah kegiatan menyusun kembali halhal yang pernah dilakukan, peristiwa berkesan yang pernah dilihat, dan perasaan tertentu yang pernah dirasakan.

Berikut emik dari informan pada tabel 2 berikut ini: 
Tabel 2 Analisis Kategori 1

\begin{tabular}{|c|c|}
\hline Pernyataan Informan & Kategorik \\
\hline $\begin{array}{l}\text { I 1:“Saya cemas karena sisa hidup saya harus menjalani } \\
\text { cuci darah terus." } \\
\text { I 2:"Waktu pertama kali saya mendengar ummm mau } \\
\text { dicuci gitu yah, ahh kaget gitu syok. Ada ummm ketakutan. } \\
\text { Tidak menerima kenapa sampai di cuci." } \\
\text { I 3:“Cemas. Takut, gelisah kuatir tidak menerima keadaan } \\
\text { kalo saya harus cuci darah.” } \\
\text { I 4:"Takut ummm gelisah jadi gimana yah aa kuatir takut } \\
\text { gimana gitu ah di jadi dikira itu teh ruang cuci darah teh } \\
\text { kaya mengerikan gitu di ruangannya teh gitu wae jadi } \\
\text { takut aja" } \\
\text { I 5:"Pertama kali percaya ngga percaya sebenarnya } \\
\text { divonis sama dokter gagal ginjal ahh sambilnya otomatis } \\
\text { pengaruh ke ke manaa dari segi pengetahuan hemodialisa } \\
\text { itu ngga, sangat awam sekali ngga tau sama sekali apa itu } \\
\text { hemodialisa, trus ini pertama kali cuci darah yah rasa } \\
\text { takut cemas juga, ahh apa lagi sih? Tidak mernerima } \\
\text { keputusan dokter yah" } \\
\text { I 6:"Aga kaget juga waktu di vonis untuk cuci darah dan } \\
\text { setengah streslah hum.... Ada sedikitlah cemas dan rasa } \\
\text { takut." } \\
\text { I } 7: " O h \text { memang menakutkan karna ini adalah pengalaman } \\
\text { pertama dan tidak terbayangkan seperti apa ko darah di } \\
\text { cuci. Jadi ada cemas ada takut..... saya pasrah saya } \\
\text { berdoa dan saya ikuti sampai hari ini nah itu saja."” }\end{array}$ & $\begin{array}{l}\text { Kognator: } \\
\text { - } \quad \text { Cemas } \\
\text { - } \text { Kaget. } \\
\text { - } \text { Tidak } \\
\text { menerima } \\
\text { keadaan. } \\
\text { - } \quad \text { Gelisah. } \\
\text { - Kuatir. } \\
\text { - } \text { Syok } \\
\text { - } \quad \text { Tidak } \\
\quad \text { percaya. } \\
\text { - } \text { Stres. } \\
\text { - } \quad \text { Pasrah. } \\
\text { - } \quad \text { Berdoa. } \\
\text { - } \text { Ketakutan }\end{array}$ \\
\hline
\end{tabular}

Penelitian yang dilakukan oleh Hagita, Bayhakki, dan Woferst (2015) menemukan tema yang memaparkan kualitas hidup pasien gagal ginjal kronik yang menjalani hemodialisis yaitu salah satunya adalah perubahan respon psikologi yaitu perasaan negatif timbul saat pertama kali mengetahui sakit gagal ginjal kronik dan harus menjalani pengobatan hemodialisis secara rutin. Perasaan negatif yang muncul terdiri dari perasaan takut, stres, syok, depresi (down), sedih, menangis dan kesal.

2) Sesudah lima tahun menjalani hemodialisis: Biasa-biasa saja atau terbiasa 3 orang; tidak terlalu cemas, pasrah kepada Tuhan, mengalami 
perubahan kondisi kesehatan lebih baik, menerima, gembira, senang, lebih fit, berhatihati dalam makan dan minum 1 orang. Berikut adalah emik dari informan dalam tabel 3 di bawah ini:
Tabel 3 Analisis Kategori 2

\begin{tabular}{|c|c|}
\hline Pernyataan Informan & Kategorik \\
\hline $\begin{array}{l}\text { I 1: "Saya biasa-biasa saja karena sudah terbiasa." } \\
\text { I 2: "Selama } 5 \text { tahun jadi me merasa biasa aja jadi } \\
\text { ngga terlalu cemas." } \\
\text { I 3: "Awalnya saya takut dan kuatir, Lama } \\
\text { kelamaan terbisa karena sudah saya pasrahkan } \\
\text { kepada Tuhan yang Maha Esa." } \\
\text { I 4: "Pengalamanna yahhh awalnya takut yah lama } \\
\text { kelamaan yah terbiasa wae jadi nerima gitu." } \\
\text { I 5: "Awalnya takut yah awalnya pertama-tama tapi } \\
\text { setelah } 5 \text { tahun dengan ngejalanin banyak } \\
\text { perubahan yang setelah hemodialisa ini kondisi } \\
\text { kesehatan lebih baik lebih sehat trus ahhh.... tapi } \\
\text { skarang setelah } 5 \text { tahun saya udah menerima yang } \\
\text { ditetapkan oleh dokter sebagai gagal ginjal dan } \\
\text { dan menjalani cuci darah terapinya, dengan rasa } \\
\text { gembira senang gitu yah." } \\
\text { I 6: "Lebih fit yah dibandingkan pada waktu cuci } \\
\text { darah seminggu dua kali." } \\
\text { I 7: "Hati-hati makan hati-hati minum sehingga yah } \\
\text { puji Tuhan Alhamdulillah luput sampai hari ini." }\end{array}$ & $\begin{array}{l}\text { Kognator: } \\
\text { - } \quad \text { Biasa-biasa saja atau } \\
\text { terbiasa. } \\
\text { - } \quad \text { Tidak terlalu cemas. } \\
\text { - } \quad \text { Pasrah kepada } \\
\text { Tuhan. } \\
\text { - } \quad \text { Kondisi kesehatan } \\
\text { lebih baik. } \\
\text { - Menerima. } \\
\text { - Gembira. } \\
\text { - } \quad \text { Senang. } \\
\text { - Lebih fit } \\
\text { - } \quad \text { Berhati-hati dalam } \\
\text { makan dan minum. }\end{array}$ \\
\hline
\end{tabular}

3. Hemodialisis mempengaruhi kualitas hidup pasien di Rumah Sakit Advent Bandung

Hagita, Bayhakki, dan Woferst (2015) menemukan 8 tema utama yang memaparkan kualitas hidup pasien gagal ginjal kronik yang menjalani hemodialisis yaitu: perubahan pemenuhan kebutuhan fisiologis. perubahan respon psikologi, respon spiritual meningkat, perubahan interaksi sosial, dukungan yang dibutuhkan, perubahan status ekonomi, dan penurunan kualitas hidup fisik dan psikologis. Berdasarkan hasil 
wawancara mendalam peneliti juga mendapati hemodialisis mempengaruhi kualitas hidup pasien. Informan mengatakan bahwa faktor yang mempengaruhi kualitas hidup adalah:

1) Ekonomi: sebelum ada BPJS, JAMKESDA, JAMKESMAS 6 dari 7 informan merasa pembayaran untuk hemodialisis terasa berat namun ketika bantuan dari pemerintah sangat membantu dan meringankan biaya pembayaran. Salah satu dari informan merasa terbantu karena menggunakan asuransi dari kantor.

Berikut adalah emik dari informan dalam tabel 4 berikut ini:

Tabel 4 Analisis Kategori 3

\begin{tabular}{|c|c|}
\hline Pernyataan Partisipan & Kategorik \\
\hline $\begin{array}{l}\text { I 1:"waktu belum ada BPJS saya terasa berat karena harus } \\
\text { bayar sendiri, setelah ada BPJS sekarang terasa ringan atau } \\
\text { terbantu." } \\
\text { I 2:"yah Alhamdulillah untung ibu ehng ada fasilitas dari } \\
\text { kantor itu di apa? dipenuhi gitu atas segi ekonominya itu." } \\
\text { I 3:"dari segi ekonomi, dulu sebelum ada BPJS saya harus } \\
\text { bayar sendiri kuatir ngga ada uang jadi cuci juga jarang. } \\
\text { Tapi puji Tuhan setelah ada BPJS semua dicover pemerintah } \\
\text { jadi sekarang saya lebih tenang menjalani cuci darah." }\end{array}$ & $\begin{array}{l}\text { Kognator: } \\
\text { Terbantu } \\
\text { oleh } \\
\text { bantuan } \\
\text { pemerintah } \\
\text { (BPJS) dan } \\
\text { asuransi } \\
\text { kantor. }\end{array}$ \\
\hline
\end{tabular}

110 | Jurnal Skolastik Keperawatan | Vol.4, No.2 | Jul - Des 2018 
I 4:"yah kalo dulu mah sebelum ada BPJS yah ngaruh sih ke faktor ekonomi the jadi ah gimana gitu jadi takut ngga kebayar harus bayar sendiri trus skrang mah Alhamdulillah yah ketolong setelah ada BPJS mah jadi ringan meringankan beban."

I 5:"sangat besar sekali pengaruhnya, dari segi ekonomi sebelumnya kan belum ada apa JAMKESDA ahh...JAMKESMAS dengan BPJS jadi pembayaran juga berpengaruh sekali ke ekonomi keluarga karna waktu itu masih dua kali seminggu bayar cukup mahal yah umm cukup lumayanlah pengeluaran ah tapi sekarang dengan adanya bp...JAMKESADA dulu ikut JAMKESDA ah itu membantu sekali ah tapi sekarang setelah ada BPJS lagi lebih membantu lagi karna semua uda di cover BPJS."

I 6:"iya pada waktu sebelum ada BPJS tu cukup mempengaruhi ya karna harus bayar cash iya sehingga pasti mempengaruhi. Setelah ada BPJS merasakan banyak keringanan ya.. terbantu."

I 7:“"memang pada tahun 2012 saya masih membayar full sampai 2013 tetapi dengan pemerintahan bapa presiden SBY kita dibantu dengan BPJS maka kita tempu jalur itu dan begitu diganti dia oleh dengan bapa Jokowi masih juga dibantu sampai sekarang. Sehingga dengan bantuan BPJS kita sangat bersyukur pemerintah memperhatikan ah rakyatnya kita sendiri dan sampai sekarang kami masih menikmati bantuan BPJS itu"

2) Emosi: dari faktor emosi didapati bahwa dari 7 informan 3 merasa cemas dan takut selama terapi berlangsung; 2 informan mengatakan bahwa emosinya biasa saja; 1 informan mengatakan bahwa lebih tenang. Berikut adalah emik dari informan dalam tabel 5 berikut ini: 


\section{Tabel 5 Analisis Kategori 4}

\begin{tabular}{|c|c|}
\hline Pernyataan Informan & Kategorik \\
\hline $\begin{array}{l}\text { I 1:"sudah terbiasa yah, pasrah saja karna sudah } \\
\text { terbiasa tadi." } \\
\text { I } 2: " s e g i \text { emosi sih ada umm apa? jadi kalo di cuci segi } \\
\text { eko eh itu apa? emosinya ada. Emosinya seperti } \\
\text { ketakutan, cemas." } \\
\text { I 3:"takut cemas kalo terjadi sesuatu terhadap saya pada } \\
\text { saat cuci darah." } \\
\text { I 4:"yah jadi lebih tenang yang dulu nya jadi emosianal } \\
\text { gitu nya jadi cepat marah sekarang mah } \\
\text { Alhamdulillah." } \\
\text { I 5:"perasaannya takut juga yah masih ada soalnya } \\
\text { pada saat cuci darah itu kadang-kadang suka kaki suka } \\
\text { apa? kram, aa apa? hipotensi trus yah jadi kadang uda } \\
5 \text { tahun lebih masih ada rasa cemas cemasnya masih } \\
\text { ada. Aaa gitu aja deh." } \\
\text { I 6:"ya biasa-biasa saja yah ngga.... apa? ngga ngga } \\
\text { maksudnya ngga terlalu mempengaruhi." }\end{array}$ & $\begin{array}{ll}\text { Kognator: } \\
\text { - } \quad \text { Cemas. } \\
\text { - } \quad \text { Takut } \\
\quad \text { selama } \\
\text { terapi } \\
\text { berlangsung. } \\
\text { - } \quad \text { Emosinya biasa } \\
\text { saja. } \\
\text { - } \quad \text { Lebih tenang }\end{array}$ \\
\hline
\end{tabular}

3) Fisik: dari faktor fisik dari 7 informan didapati bahwa cepat capek 4 orang; sesak, kulit kering, motorik berkurang, hb menurun 1 orang; tidak fit, nyeri persendian 2 orang; lelah 3 orang. Berikut adalah emik dari informan pada tabel 6 berikut ini: 
Tabel 6 Analisis Kategori 5

\begin{tabular}{|c|c|}
\hline Pernyataan Informan & Kategorik \\
\hline $\begin{array}{l}\text { I 1:"tidak ada perubahan yang signifikan hanya } \\
\text { sering cepat capek dan sesak." } \\
\text { I 2:"secara fisik ahhh itu merasakan ngga enak di } \\
\text { badan, tidak pit, cepat capek, dan lelah." } \\
\text { I } 3: \text { "merusak tubuh tidak fit seperti dulu lagi, cepat } \\
\text { cape dan lelah." } \\
\text { I 4:"setelah menjalani sekarang fisiknya cepat cepat } \\
\text { apa? cepat lelah jadi kalo mengerjakan sesuatu te } \\
\text { kalo kaya nyapu gitu harus diam dulu karena cepat } \\
\text { cepat aja capenya." } \\
\text { I 5:"perubahan fisik yang dialami ah kondisi fisik } \\
\text { apa? lebih sering apa? banyak yang kerasa sekarang } \\
\text { karna waktu terutama setelah cuci darah kulit jadi } \\
\text { lebih kering, aa tulang lutut saraf aa } \\
\text { persendisendian tulang dengan a rasa sakit aa trus } \\
\text { kadang um hb saya turun, itu aja sih bang." } \\
\text { I 6:"ahh yah sedikit ada penurunan. Kususnya juga } \\
\text { bagian lutut yah nyeri iya....... motoriknya jadi aga } \\
\text { berkurang yah." }\end{array}$ & 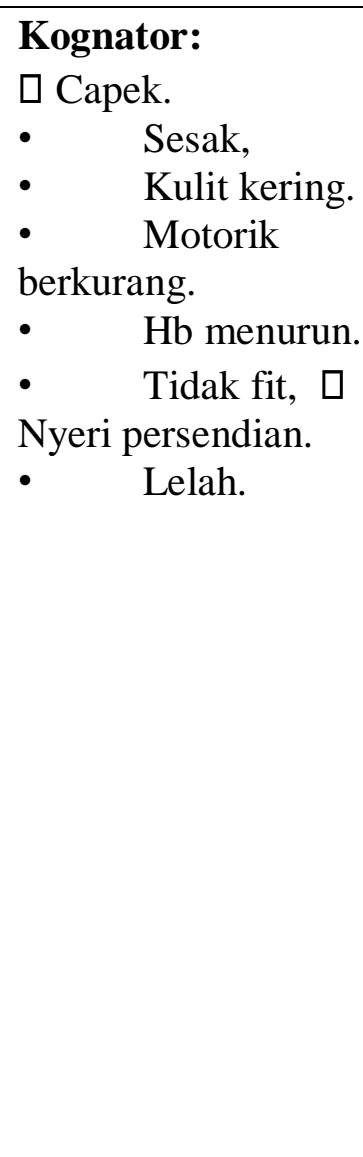 \\
\hline
\end{tabular}

4) Sosial: 1 informan merasa minder dengan masyarakat; 1 informan lagi hubungan dengan istri menurun. Berikut adalah emik dari para informan tentang pengaruh pada tabel 4.7 berikut ini:

Tabel 7 Analisis Kategori 6

\begin{tabular}{|c|c|}
\hline Pernyataan Informan & Kategorik \\
\hline $\begin{array}{l}\text { I 3:“....tapi dengan masyarakat uuh apa suka aga minder gitu.” } \\
\text { I 7:“hubungan saya dengan istri itu kok jadi jauh menurun kadang- } \\
\quad \text { kadang kita punya }\end{array}$ & $\begin{array}{l}\text { Kognator: } \\
\text { - } \quad \text { Merasa minder. } \\
\text { - } \quad \text { Hubungan dengan istri }\end{array}$ \\
\hline niat indah tapi tenaga ngga cukup untuk itu." & menurun. \\
\hline
\end{tabular}


5) Spiritual: lebih dekat dengan Tuhan 7 orang; berpasrah 1 orang, tetap melayani Tuhan 2 orang; merubah cara berdoa khususnya mengucap syukur kepada Tuhan 1 orang. Berikut adalah emik dari informan pada tabel 8 berikut ini:

Tabel 8 Analisis Kategori 7

\begin{tabular}{|c|c|}
\hline Pernyataan Informan & Kategorik \\
\hline 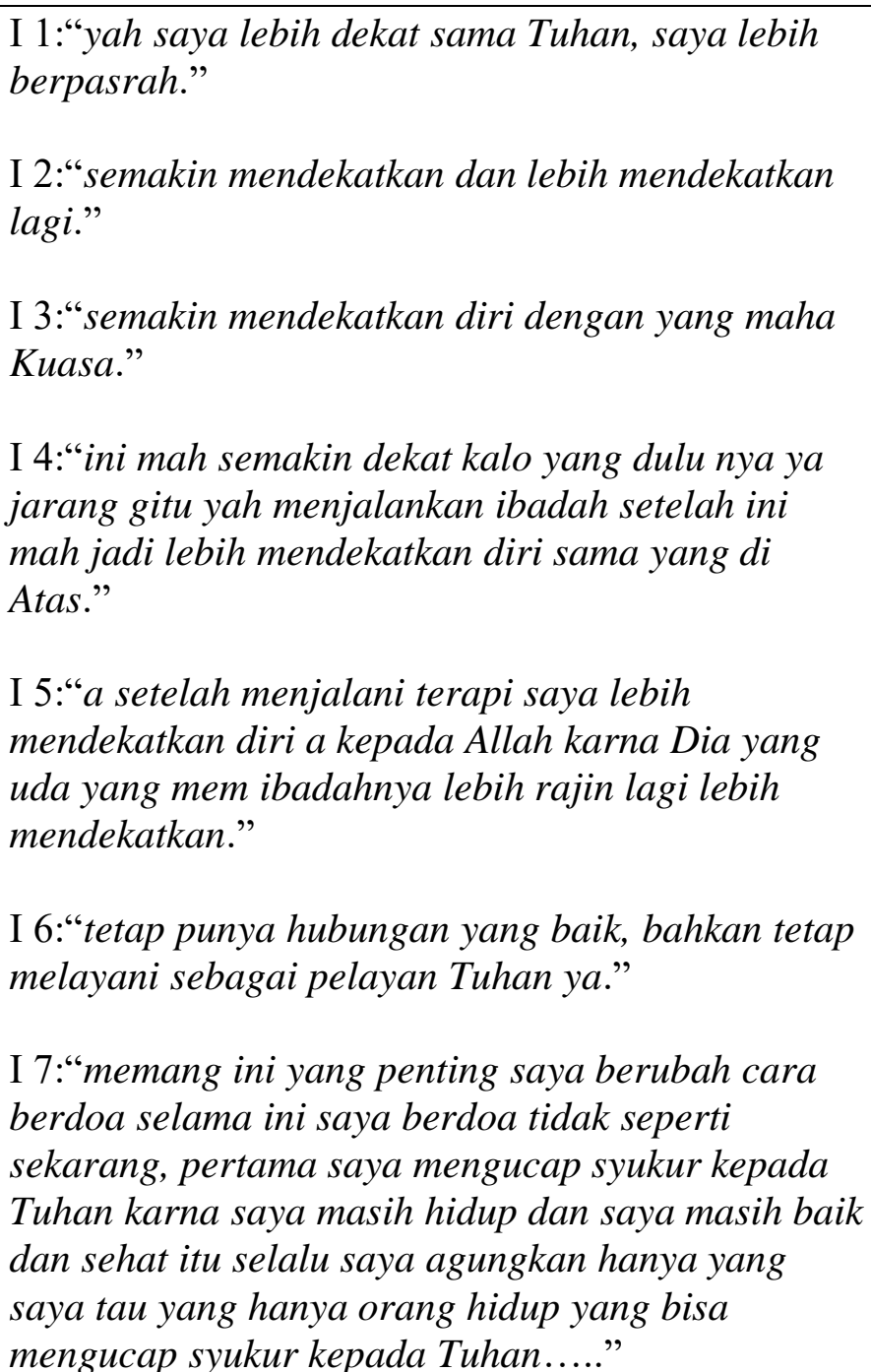 & $\begin{array}{l}\text { Kognator: } \\
\text { - Lebih dekat dengan } \\
\text { Tuhan } 7 \text { orang; } \\
\text { - } \quad \text { Berpasrah } 1 \text { orang, } \\
\text { - } \quad \text { Tetap melayani } \\
\text { Tuhan } 2 \text { orang; } \\
\text { - } \quad \text { Merubah cara berdoa } \\
\text { - } \quad \text { Mengucap syukur } \\
\text { kepada Tuhan } 1 \\
\text { orang }\end{array}$ \\
\hline
\end{tabular}

Hasil wawancara mendalam terhadap informan didapati bahwa faktor yang paling mempengaruhi kualitas hidup adalah fisik. Enam dari tujuh informan mengatakan bahwa fisik sangat berpengaruh terhadap kualitas hidup pasien. Menurut hasil penelitian yang dilakukan oleh Nurani dan Mariyanti 
(2013) segi emosional adalah masa dimana motivasi untuk meraih sesuatu sangat besar yang didukung oleh kekuatan fisik yang prima. Pasien GGK harus menjalani rutinitas HD keadaan ini memberikan perubahan-perubahan dalam diri mereka, baik secara fisik dan emosional. Adanya keterbatasan dalam melakukan aktifitas sehari-hari.

Berikut adalah emik dari informan pada tabel 9 berikut ini:

Tabel 9 Analisis Kategori 8

\begin{tabular}{|l|l|}
\hline \multicolumn{1}{|c|}{ Pernyataan Informan } & Kategorik \\
\hline I 1:"fisik iya mah, cepat cape." & $\begin{array}{l}\text { Kognator: } \\
\text { I Fisik }\end{array}$ \\
I 2: "Ya itu fisik, fisik semakinnn menurun." & \\
I 4: "Fisik mah yah semakin menurun karna \\
sering lelah itu sama cape itu."
\end{tabular}

4. Koping pasien dalam menjalani hemodialisis di Rumah Sakit Advent Bandung

Informan berusaha untuk menangani tantangan yang dihadapi selama menjalani hemodialisis yaitu: menemukan solusi lain contohnya membawa permen untuk mengatasi rasa ingin makan yang banyak, mengikuti anjuran dokter dan perawat, mendekatkan diri pada Tuhan, makan dan minum teratur, membatasi minum, berdoa dan bersyukur kepada Tuhan. Koping yang adaptif dapat memperbaiki kualitas hidup pasien gagal ginjal kronis yang menjalani 
terapi hemodialis (Desnauli, 2011, hal. 190).

Metode koping yang dimiliki oleh para informan sudah efektif. Berdasarkan hasil penelitian yang dilakukan oleh Widjayanti (2017) bahwa strategi koping berhasil menjadi senjata untuk menangani permasalahan penderita Gagal Ginjal Kronik. Penelitian ini menunjukan adanya peran agama sebagai alat penanganan masalah yang sangat mendominasi. Strategi koping baik itu problem focused coping maupun emotional focused coping dipadukan dengan kekuatan agama menjadikan suatu perpaduan yang sangat efektif dalam menghadapi permasalahan-permasalahan yang dihadapi seorang penderita gagal ginjal kronis untuk menghadapi masalahmasalah fisiologis dan psikologisnya. Berikut emik dari para informan pada tabel 10 berikut ini:

Tabel 10 Analisis Kategori 9

\begin{tabular}{|c|c|}
\hline Pernyataan Informan & Kategorik \\
\hline $\begin{array}{l}\text { I: } \quad \text { "Ah saya slalu memem mem } \\
\text { bawa penggantinya yaitu permenlah". } \\
\text { I 2: "Kalua mau tetap sehat fisik ikut dan boleh.... }\end{array}$ & $\begin{array}{l}\text { Kognator: } \\
\square \text { Menemukan solusi lain. }\end{array}$ \\
\hline $\begin{array}{l}\text { Harus mengikuti anjuran dokter" } \\
\text { I 3: "Kalo mau tetap sehat dan fit harus mengikuti anjuran dari } \\
\text { dokter dan perawat dan lebih mendekatkan diri kepada } \\
\text { Tuhan." } \\
\text { I 4: "Nah strateginya yah harus mengikuti ini aja anjuran dokter } \\
\text { sama perawat biar tetap fit". } \\
\text { I 5: "Supaya supaya ah kondisi fisik lebih fit ah harus memenuhi } \\
\text { apa? ah peraturan ketetapan dari dokter supaya makan dan } \\
\text { minum lebih teratur lagi gitu dan ngga boleh apa sih bang } \\
\text { aaa Minum di batasin". } \\
\text { I 6: "Ya berusaha sebaik-baiknya me untuk melakukan yang terbaik } \\
\text { dalam hal makan minum dan juga waktu yah". } \\
\text { I 7: "Yang paling pertama saya selalu berdoa dan bersyukur kepada } \\
\text { Tuhan." }\end{array}$ & $\begin{array}{l}\quad \text { Mengikuti anjuran } \\
\square \quad \text { dokter dan perawat. } \\
\square \quad \text { Mendekatkan diri } \\
\square \quad \text { pada Tuhan. } \\
\square \quad \text { Makan dan minum teratur. } \\
\text { Membatasi minum. } \\
\text { Berdoa dan bersyukur } \\
\quad \text { kepada Tuhan. }\end{array}$ \\
\hline
\end{tabular}


Farida (2010) dalam penelitiannya mendapati bahwa pasien hemodialisis mengalami perubahan terhadap kondisi fisik, psikologis, sosial, ekonomi dan spiritual namun sebagian besar pasien sudah dapat beradaptasi dengan kondisi yang dihadapi. Hagita, Bayhakki, dan Woferst (2015) menemukan tema yang memaparkan kualitas hidup pasien gagal ginjal kronik yang menjalani hemodialisis yaitu salah satunya adalah respon spiritual meningkat yaitu semakin mendekatkan diri dengan Tuhan dengan meningkatkan ibadah dan pasrah, karena adanya persepsi bahwa tidak selamanya bisa bertahan hidup karena penyakit dan ketergantungan pada mesin hemodialisis.

\section{KESIMPULAN DAN SARAN}

\section{Kesimpulan}

Berdasarkan kesimpulan dari penelitian yang telah dilakukan pada 7 informan pasien hemodialisis di Rumah Sakit Advent Bandung maka disimpulkan sebagai berikut:

1. Gambaran pengalaman pasien dalam menjalani hemodialisis di Rumah Sakit Advent Bandung terbagi menjadi dua bagian yaitu:

1) Pertama kali menjalani hemodialisis adalah cemas, kaget, syok, ketakutan, tidak menerima, gelisah, kuatir, tidak percaya, stres, pasrah dan berdoa.

2) Setelah 5 tahun menjalani hemodialisis adalah biasa-biasa saja, tidak terlalu cemas, pasrah kepada Tuhan, mengalami perubahan, kondisi kesehatan lebih baik, menerima, gembira, senang, lebih fit, berhati-hati dalam makan dan minum

2. Hemodialisis mempengaruhi kualitas hidup pasien di Rumah Sakit Advent Bandung didapati bahwa faktor-faktor yang mempengaruhi sebagai berikut:

1) Ekonomi: didapati 6 dari 7 informan mengatakan bahwa faktor ekonomi sangat mempengaruhi ketika belum menggunakan bantuan dari pemerintah (BPJS) terasa sangat berat dan tidak mampu karena harus membayar sendiri, salah satu dari 6 informan ini sangat kuatir sehingga mengaku jarang melakukan hemodialisis. Namun ketika menggunakan bantuan pemerintah terasa ringan, terbantu atau tertolong karena adanya bantuan pemerintah yang mengcover seluruh biaya hemodialisis.

2) Emosi: dari faktor emosi didapati bahwa dari 7 informan 3 merasa cemas dan takut selama terapi berlangsung, 2 informan mengatakan bahwa emosinya biasa saja, dan 1 informan mengatakan bahwa lebih tenang.

3) Fisik: dari faktor fisik dari 7 informan didapati bahwa cepat capek 4 orang, sesak 1 orang, tidak fit 2 orang, lelah 3 orang, kulit kering 1 orang, nyeri persendian 2 orang, hb menurun 1 orang, dan motorik berkurang 1 orang.

4) Sosial: didapati ada 2 informan yang merasa sosialnya terpengaruh, 1 informan merasa minder dengan masyarakat dan 1 informan lagi hubungan dengan istri menurun

5) Spiritual: dari semua informan faktor spiritual semakin meningkat yaitu: lebih dekat dengan Tuhan, berpasrah, tetap melayani Tuhan, 
dan merubah cara berdoa khususnya mengucap syukur kepada Tuhan.

(6) Faktor yang paling berpengaruh terhadap kualitas hidup pasien adalah

fisik

3. Koping pasien dalam menjalani hemodialisis di Rumah Sakit Advent Bandung adalah informan berusaha untuk menangani tantangan yang dihadapi selama menjalani hemodialisis yaitu: menemukan solusi lain contohnya membawa permen untuk mengatasi rasa ingin makan yang banyak, mengikuti anjuran dokter dan perawat, mendekatkan diri pada Tuhan, makan dan minum teratur, membatasi minum, berdoa dan bersyukur kepada Tuhan.

\section{Saran}

Peneliti memberikan saran dari hasil penelitian yang dapat berguna bagi pasien hemodialisis, bidang keperawatan, dan bidang penelitian adalah sebagai Sberikut:

1) Pasien hemodialisis: sebagai saran bagi pasien agar lebih menjaga ketaatan terhadap diit makanan dan pembatasan asupan cairan sehingga kondisi fisik tetap terjaga.

2) Bidang keperawatan: sebagai tambahan informasi dan ilmu pengetahuan dalam proses keperawatan dalam pemberian asuhan keperawatan pada pasien dalam menjalani hemodialisis.

3) Bidang penelitian: sebagai bahan masukan untuk penelitian selanjutnya dalam hal mengetahui kepatuhan pasien dalam menjalani hemodialisis, apakah lama menjalani hemodialisis dapat berpengaruh terhadap kualitas hidup pasien dan juga apakah pengalaman negatif berpengaruh pada kepatuhan atau ketaatan dalam menjalani hemodialisis.

\section{DAFTAR PUSTAKA}

Alfiannur., Nauli., \& Dewi. (2015). Hubungan Antara Kecerdasan Spiritual Dengan Tingkat Kecemasan Pasien Gagal Ginjal Kronik Yang Menjalani Hemodialisa. JOM, (2)2: 11061115.

Asmadi. (2008). Konsep Dasar Keperawatan. Jakarta: ECG.

Baradero., Dayrit., dan Siswandi. (2009). Seri Asuhan Keperawatan Klien Gangguan Ginjal. Jakarta: EGC.

Baughman, C. Diane \& Hackley. (2009). Keperawatan Medikal bedah Buku Saku untuk Brunner dan Suddarth, Edisi 1, Alih bahasa: Yasmin Asih, Editor Monica Ester. Jakarta: EGC.

Dani., Utami., \& Bayhakki. (2015). Hubungan Motivasi, Harapan, Dan Dukungan Petugas Kesehatan Terhadap Kepatuhan Pasien Gagal Ginjal Kronik Untuk Menjalani Hemodialisis. JOM, (2)2: 1362-1371.

Desfrimadona. (2016). Kualitas Hidup Penderita Gagal Ginjal Kronik Dengan Hemodialisa di RSUP Dr. M. Djamil Padang Tahun 2016. FIK. Padang: Universitas Andalas. 
Desnauli., Nursalam., \& Efendi. (2011). Indikator Kualitas Hidup Pasien Gagal Ginjal Kronis Yang Menjalani Hemodialisa Berdasarkan Strategi Koping. Fakultas Keperawatan. Surabaya: Universitas Airlangga.

Dharma. (2011). Metodologi Penelitian Keperawatan: Panduan Melaksanakan dan Menerapkan Hasil Penelitian. Jakarta: Trans InfoMedia.

Ekantari., Suswardani., \& Kusumawati. (2012). Hubungan Antara Lama Hemodialisa dan Faktor Komorbiditas Dengan Kematian Pasien Gagal Ginjal Kronik Di RSUD DR. Moewardi. Surakarta: Universitas Muhammadiyah.

Farida. (2010). Pengalaman Klien Hemodialisis Terhadap Kualitas Hidup Dalam Konteks Asuhan Keperawatan Di RSUP Fatmawati Jakarta. Fakultas Ilmu Keperawatan. Jakarta: Universitas Indonesia.

Hagita., Bayhakki., \& Woferst. (2015). Studi Fenomenologi Kualitas Hidup Pasien Gagal Ginjal Kronik Yang Menjalani Hemodialisis Di Rsud Arifin Achmad Pekanbaru. JOM, (2)2: 1032-1040.

Indonesian Renal Registry (IRR). (2013). Penderita Gagal Ginjal Kronik. [Online]. Available: www.indonesianrenalregistry.or g [20 Januari 2018].

Indrawan., \& Yaniawati. (2014).
Metodologi Penelitian

Kuantitatif, Kualitatif, dan Campuran Untuk Manajemen, Pembangunan, dan Pendidikan. Bandung: Penerbit PT Refika Aditama.

Ipo., Aryani., \& Suri. (2016). Hubungan Jenis Kelamin Dan Frekuensi Hemodialisa Dengan Kualitas Hidup Pasien Gagal Ginjal Kronik Yang Menjalani Hemodialisa Di Rumah Sakit Umum Daerah Raden Mattaher Jambi. Jurnal Akademika Baiturrahim, (5): 46-55.

Kamaluddin \& Rahayu. (2009). Analisis Faktor-Faktor Yang Mempengaruhi Kepatuhan Asupan Cairan Pada Pasien Gagal Ginjal Kronik Dengan Hemodialisis Di Rsud Prof. Dr. Margono Soekarjo Purwokerto. Jurnal Keperawatan Soedirman (The Soedirman Journal of Nursing), (4)1: 20-31.

Kamus Besar Bahasa Indonesia (KBBI). (2012:3)

Moleong. (2012). Metodologi Penelitian Kualitatif. Edisi Revisi. Bandung: Remaja Rosdakarya.

Pranandari dan Supadmi. (2015). Faktor Risiko Gagal Ginjal Kronik Di Unit Hemodialisis Rsud Wates Kulon Progo. Jurnal Farmaseutik, (11)2: 317-320.

Sudjadi \& Laila. (2010). Biologi Sains Dalam Kehidupan. JakaIta: Yudistira. 
Sugiyono. (2015). Metodologi Penelitian Kualitatif. Bandung: Alfabeta.

Sujarweni, V.W. 2014. Metodologi Penelitian Keperawatan. Yogyakarta: Gava Media.

Trianto. (2008). Pasti Bisa Pembahasan Tuntas Kompetensi Bahasa Indonesia. Jakarta: Erlangga.

Veronika. (2017). Peningkatan Kualitas Hidup Pada Penderita Gagal Ginjal Kronik Yang Menjalani Terapi Hemodialisa Melalui Psychological Intervention Di Unit Hemodialisa Rs Royal Prima Medan Tahun 2016. Fakultas Keperawatan dan Kebidanan. Medan: Universitas Prima Medan.

Widjayanti. (2017). Hubungan Mekanisme Koping Individu Dengan Tingkat Kecemasan Pada Pasien Gagal Ginjal Kronik Yang Menjalani Hemodialisis Di Bangsal Teratai RSUD dr. Soediran Mangun. Program Studi S-1 Keperawatan. Surakarta: Sekolah Tinggi Ilmu Kesehatan Kusuma Husada 